Volodymyr Stepashko,

Doctor of Pedagogy, associate professor, professor of the Department of Education Management and Adult Education, Hryhoriy Skovoroda State Pedagogical University of Pereyaslav-Khmelnytsky, 34, Sukhomlynskoho Str., Pereiaslav-Khmelnytskyi, Ukraine

\title{
TECHNOLOGY OF COMPETITIVE SELECTION OF CANDIDATES FOR THE POSITION OF A RECTOR OF A HIGHER EDUCATIONAL INSTIUTION
}

The paper presents the issue of scientifically grounded professional competitive selection of candidates to fill the position of a leader of a higher educational institution on the basis of competence-based, factorial and resultant approaches. We have developed a qualimetric (factorial-criterial) model of evaluating qualitative indicators of development level, a program of managerial competence development, a theoretical model of selecting candidates for the position of a leader of a higher educational institution. There are four factors in the qualimetric model: competitiveness, creative potential, managerial competence, conditions for managerial competence formation, which determine the effectiveness of university leader's management activities. The program of university leader's managerial competence development involves the following organizational measures: international internship according to recognized programs of EU countries, international internship at career development courses according to certified programs of EU countries, career development courses in the system of postgraduate education of Ukraine according to special elective programs, participation in international grant programs, participation in meetings of specialized academies of the National Academy of Sciences of Ukraine, acmeological counseling regarding professional development. The theoretical model of selecting candidates for the position of a higher educational institution leader consists of four stages. The first stage involves subsystems of computer expert diagnostics (the questioning of applicants) and preliminary competitive selection. At the second stage, the founder organizes intelligence testing (a specialized test and the test for assessing knowledge of mathematics and command of foreign languages). At the third stage ("Expert evaluation"), the founder organizes interview for a candidate with the personnel expert panel of the Ministry of Education and Science of Ukraine alongside with democratic procedure of university rector election. At the fourth stage, quantitative indicators of the level of applicants' managerial competence development are evaluated on the basis of the qualimetric model. It has been recommended to implement a transparent procedure of assessing the qualitative characteristics of the level of managerial competence of candidates for leadership positions at higher educational institutions. The system of candidate selection should include a subsystem of the formation and training of managerial personnel reserve for universities, information subsystem containing personal information about the candidates. Also, we find it reasonable to spread the use of expert systems, new technologies of competitive selection for the position of a university leader; to improve the current legislation that regulates the procedure of selecting candidates based on the experience of European countries.

Keywords: professional selection, qualimetric model, monitoring, selection model, management.

\section{Introduction}

An important factor of preservation and development of higher education system and improvement of its quality is state personnel policy. Modern higher education requires high level of professionalism of a higher educational institution leader as well as his/her technological readiness for implementing functions related to educational institution management.

State personnel policy involves evaluation of work performed by a university leader and its academic stuff by the public, colleagues, students according to the criteria that are the basis for the development of standards.

Competitive selection and professional development of a university leader is one of the requirements to the quality of higher education in Ukraine. The results of educational activities of a higher educational institution depend largely on leader's professionalism.

Recommendations of the EU (IWA2: 2007) on quality management include the following principles in socioeducational systems management: process approach, the understanding of core competency, general optimization; sustainable leadership; collaboration with partners; engaging qualified personnel; continuous development; focusing on students' values; quick response; autonomy [8].

The processes of personnel selection were described in the works of foreign scientists: G. Dessler (1997) [2], B. Karloff (1996) [5] R. Rou (2012) [7], G. Hofstade (2001) [12].

M. Hennen and I. Freeman believe that organizational changes should be introduced through personnel selection and the filling of vacancies (1989) [11].

American researcher of organization structure and strategy A. Chandler pointed out at the decisive role of a manager in organization development (1962) [10], as a university leader is a guarantor of the quality of educational services, a strategist; he/she forms human resources of an organization, implements university's mission in practice; creates favorable organizational, pedagogical, psychological conditions that provide effective performance of a higher educational institution, performs administrative functions (organization- 
al, executive and predictive ones, coordination, control, and decision-making).

A total model of organization management by R. Likert (4T system) - "impact-interaction" - can be used at the university upon condition that its leader has a high level of knowledge and experience, good command of the latest technologies of managing a higher educational institution, stable relationships between him/her and subordinates.

The issue of education managers' psychological readiness for management activities in postgraduate pedagogical education was studied by O. Bondarchuk, N. Kolominskyi, L. Karamushka. Scientific and methodological principles of managing lifelong learning of adults and educational institution leaders on the basis of competence-based approach were substantiated by V. Maslov, V. Oliinyk. Organizational and pedagogical conditions for forming teaching staff at higher educational institutions were determined by V. Stepashko (2004) [9]. However, researchers do not take into account the factorial and resultant approach to personnel selection, which have recently become relevant due to democratization, entering the European educational and scientific environment, increased competitiveness between higher educational institutions.

The issue of competitive selection of leaders for educational institutions, particularly universities, remains less explored in domestic science and practice of education system management.

The aim of the paper is to substantiate theoretical and methodological basis for competitive selection of leaders for Ukrainian universities and use this basis to develop the standard of professional management of competence-based development of university leaders as well as the program of their managerial competence development.

Research methods: means of selecting university leaders have been determined, namely legislative framework, cover letters, recommendations, psychological tests, standards of professional management, job description, copies of documents certifying qualifications, code of conduct, program of managerial competence development; selection methods: competition, group evaluation of performance, review of recommendations, assessment of candidates' documents, specifying candidate's competitive advantages.

\section{Discussion}

Candidates for the position of a higher educational institution leader, according to the Law of Ukraine "On Higher Education", have to meet the following requirements: to be fluent in the state language; to have academic title and degree, minimum 10 years of work experience as a member of academic staff; to be the citizen of Ukraine [1].

Taking into account the requirements provided by the current legislation on higher education and personnel expert panel of the Ministry of Education and Science of Ukraine (MES), the following general requirements to the position of a higher educational institution leader can be formulated: having citizenship of Ukraine; being not older than 55 years; having academic degree and academic title; minimum 10 years of work experience as a member of academic staff; command of the state and foreign languages; publications in domestic and foreign professional journals; honorary titles; state awards; the results of performance review, career development (including foreign internship programs); annual reports on performing contractual obligations; contribution to the university development (achievements in international cooperation, science; preparing qualified personnel for higher education and national economy; development of material and technical facilities of a university).

The report must present achievements of a leader as a professional manager, self-analysis of the work done during a year and differ from the results of the main kinds of activities of a higher educational institution.

Grounds for electing a university leader is a competition that is announced not later than two months before expiration of a contract [1, p. 14].

The founder shall announce a competition to fill the vacancy of a leader of a higher educational institution not later than two months before expiration of the contract. The founder is considering propositions concerning candidates for the position of a university rector during two months starting from the date when the vacancy is announced; within ten days after termination of submitting applications, the founder introduces applicants who meet the requirements of the Law of Ukraine "On Higher Education" for voting [1, p.14 ].

A university leader is elected by means of secret ballot by a majority vote $(50 \%)$. Following the voting, the founder concludes a contract with the elected person for a term of five years [1, p.14].

Propositions concerning the candidates for the position of a university rector can be submitted by academic boards of universities, experts from the independent agency for evaluating the quality of higher education. While selecting candidates for the position of a university rector, it is necessary to consider recommended practice concerning peculiarities of the voting system and procedure of electing a university leader following the results of competitive selection, which is regularly organized by founders under applicable law [6], proposals and recommendations of experts from the independent agency for evaluating the quality of higher education, the personnel expert panel of the MES.

The founder can create a data base with the reserve of candidates to fill administrative posts. The reserve of the candidates for universities (colleges, vocational schools) is formed of students obtaining Master degree in the specialty 073 "Management". Organizational condition for improving the quality of management activities is probationary period for rectors who are appointed to this position for the first time.

Unfortunately, the recommended practice concerning peculiarities of the voting system and procedure of electing university leaders do not describe criteria and parameters, which are used to select candidates for the position of a university leader, and only describe procedural aspects of organizing the voting.

At the same time, the term "leader", not "acting rector" is used; insufficient attention is paid to the role of academic 
boards in the procedure of electing candidates at the preparatory stage.

The paragraph 27 of the recommended practice does not specify, which institutional body approves the list of candidates applying for the position of a rector of a state higher educational institution and submits it to the Certifying Commission of the MES for consideration, examines minutes of meetings of university units concerning nomination and support of candidates (in case the candidates are not elected on the basis of the report presented by a current rector).

The founder uses public communications to announce the competition not later than two months before termination of the contract of a current rector or during the week from the vacancy introduction; he/she places an advertisement on his/her personal and university website [6]. Besides, it is not specified, what guiding document defines the time period for holding general meeting of the staff. According to the Resolution of the Cabinet of Ministers of Ukraine No. 726 dated 5 December 2014 "Some issues of implementing the article 42 of the Law of Ukraine "On Higher Education", universities develop "Regulations on the organizational committee on holding the election of a higher educational institution rector" and "Regulations on election committee on holding rector election".

According to the model of ideal bureaucracy by $\mathrm{M}$. Weber, it is reasonable to organize selection of candidates for vacant positions on the basis of competence-based, factorial and cyber (resultant) approaches.

For selecting and forming the reserve of future university leaders and development of their creative potential, we have developed a theoretical model of selecting candidates for the position of a higher educational institution leader, which consists of four stages.

The first stage consists of subsystems of computer expert diagnostics (questioning of applicants based on the expert system "University Leader") and preliminary competitive selection in accordance with the Law of Ukraine "On Higher Education". These procedures should be carried out simultaneously to obtain objective data about the applicant and some additional information. When developing the questionnaire, it is necessary to consider factors specified in the qualimetric model, including "competitiveness", "system qualities", "managerial competence", "conditions for professional competence formation". It is necessary to include the questions that are not specified by the requirements of the Law of Ukraine "On Higher Education", but help get additional information reflecting the applicant's achievements (the number of publications in international journals, achievements in international collaboration of a higher educational institution, state awards, academic titles, annual reports on performing contractual obligations).

In the process of competitive selection on the basis of documents, the founder checks if the applicants meet the requirements to leader's position specified by the first part of the article 42 of the Law of Ukraine "On Higher Education". The documents submitted by the candidates indicate equal rights for the vacant position. In the process of the secret ballot, academic staff members, representatives of the student government assess the applicant's qualities, organizational skills, his/her contribution to the development of the institution, and the electoral program [1].

At the second stage (it is referred to the subsystem "Computer testing"), the founder organizes intelligence testing (a specialized test and test for assessing knowledge of mathematics and command of foreign languages).

At the third stage ("Expert evaluation"), the founder organizes interview for the candidate with the personnel expert panel of the MES alongside with democratic procedure of election of a university rector. When making the resolution, the experts consider the results of computer expert diagnostics of the first and the second stages of professional selection of candidates for the position of a university rector, secret ballot of the majority of votes.

At the fourth stage of the formation of the reserve of professional managers and development of their managerial competence, while assessing quantitative indicators of the level of applicants' managerial competence development on the basis of the qualimetric model, experts focus on the following factors: "competitiveness" and "conditions for professional competence formation".

If a university leader has been elected for the first time, it is advisable to organize the monitoring of qualitative indicators of the level of his/her managerial competence development within the period of five years on the basis of the factorial-criterial model and analyze the dynamics of managerial competence development in accordance with the organizational measures of the development program.

If the candidate is elected for the second time, the competition committee of the university and the personnel expert panel of the MES, apart from the regulatory requirements for the candidates and the results of computer diagnostics (tests and questionnaires), take into account the results of the monitoring of the level of managerial competence formation for the past five years, analysis of annual reports submitted to the Ministry of Education and Science of Ukraine available on the university website. Academic staff members have the right to become familiar with the results of expert diagnostics at the first and second stages of the candidate selection. The candidates who did not receive the required number of votes are recorded in the reserve of professional manager.

The fourth stage involves the development of managerial competence of a university leader according to the content of program. We have developed a program of college leaders' managerial competence development based on job requirements, which should be annually adjusted according to the content and qualitative indicators of the factorialcriterial model.

Using the resultant and factorial approaches to university management, we have developed the qualimetric (factorial-criterial) model of evaluating qualitative indicators of the level of managerial competence development in leaders of higher educational institutions (adapted to the conditions of higher educational institution's functioning), which is based on the methodology developed by H. Yelnykova [4] (Table $1)$. 
Table 1.

Qualimetric (factorial-criterial) model of evaluating qualitative indicators of the level of higher educational institution leader's managerial competence development

(Standard of qualified management of university leader's competence development)

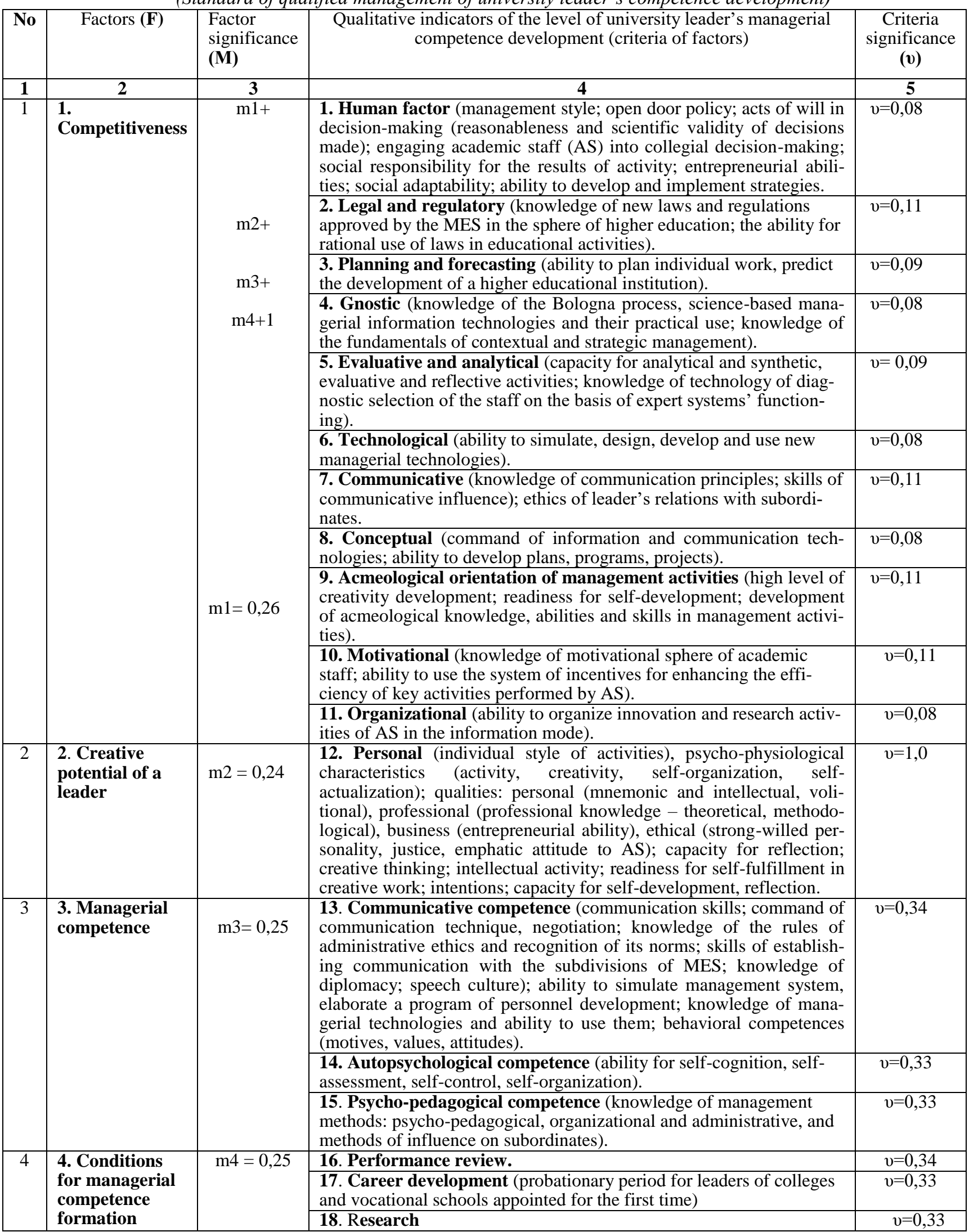


There are four factors $(\mathrm{F})$ in the qualimetric model: competitiveness, creative potential, managerial competence, conditions for managerial competence formation, which determine the effectiveness of university leader's managerial activities. The significance of the four factors (M) equals to $1:(m 1+m 2+m 3+m 4)=1$. The factor "competitiveness" involves the following components (criteria): human factor, legal and regulatory criterion, planning and forecasting, gnostic, evaluative and analytical, technological, communicative, and conceptual criteria, acmeological orientation of management activities, motivational, and organizational criteria.

The factor "creative potential of a leader" involves personal component; the factor "managerial competence" - the communicative, autopsyhological, psychopedagogical ones; and the factor "conditions for managerial competence formation" includes the following criteria: performance review, career development, research. Each criterion is characterized by corresponding indicators. The significance of criteria (v) in total for each factor equals to 1 .

Let us consider evaluation of components of university leaders' managerial competence according to the factorial-criterial model. It is necessary to include corresponding value of the coefficient of concordance into the dark field of the model. If, according to the results of the questionnaire, most of the academic staff members are not satisfied with the quality of management of the leader, he/she receives 0 points (the criterion is not identified); are satisfied for less than $50 \%-0.25$ points (the criterion is slightly expressed); are satisfied for $50 \%-0.50$ points; are satisfied for more than $50 \%-0.75$ points. If the quality of management is actually satisfactory, the leader receives 1 point.

The effectiveness of leader's management activities is determined by a combination of factors. The levels of management activities of a leader are determined on the basis of group expert assessment of quality indicators (factors) according to the factorial-criterial model ("competitiveness", "creative potential of a leader", "managerial competence", "conditions for managerial competence formation") according to the scale parameters: 0 - the criterion is not identified; 0.25 - the criterion is slightly expressed (the formal level); 0.5 - the criterion is expressed for $51-65 \%$ (the reproductive level); 0.75 - the criterion is expressed for $66-75 \%$ (the functional level); 1 - the criterion is expressed for $76-100 \%$ (the creative level) [3].

The levels of management activities of a leader correspond to the following meanings: formally working (from 0 to 0.50 ); reproductive (from 0.51 to 0.65 ); functional (from 0.66 to 0.75 ); creative (from 0.76 to 1.00 ). The number of points is calculated as follows: it is the index that reflects ratio of the number of requirements carried out in leader's professional activities to the total number of the requirements envisaged by the model [3, $\mathrm{p}$. 314]. For example, the model involves seven requirements, but leader's management activities, according to expert assessment, meets only 2 requirements. Expression coefficient will amount to $2 / 7=0.28$ points. Seven requirements were developed for each criterion (18) respectively (Table 2). 


\section{Requirements to the components of university leader's} managerial competence (standard of management activities)

\begin{tabular}{|c|c|}
\hline $\begin{array}{l}\text { Components of } \\
\text { managerial competence }\end{array}$ & Requirements \\
\hline $\begin{array}{l}\text { Content-related } \\
\text { (human factor) }\end{array}$ & $\begin{array}{l}\text { Following open door policy; reasonableness and scientific validity of decisions made; engaging aca- } \\
\text { demic staff (AS) into collegial decision-making; social responsibility for the results of activity; entre- } \\
\text { preneurial abilities; high level of social adaptability; ability to develop and implement strategies, } \\
\text { knowledge of the basic requirements to management activities, principles, forms and methods of } \\
\text { management; ability to simulate management activities; ability for searching, processing and creating } \\
\text { information resources to implement the content of management functions to the full. }\end{array}$ \\
\hline Legal and regulatory & $\begin{array}{l}\text { Knowing and adhering to legal and normative framework in management activities; ability to analyze } \\
\text { legal information on the platform "LIGA: ZAKON"; participation in the development of local regula- } \\
\text { tory documents, standards of management activity. }\end{array}$ \\
\hline Planning and forecasting & $\begin{array}{l}\text { Ability to plan and correct the content of the basic functions of managing a higher educational institu- } \\
\text { tion, to plan career development of the academic staff, and predict the development of a higher educa- } \\
\text { tional institution. }\end{array}$ \\
\hline Gnostic & $\begin{array}{l}\text { Knowledge of the Bologna process, science-based managerial information technologies and their } \\
\text { practical use; knowledge of the fundamentals of contextual and strategic management }\end{array}$ \\
\hline Evaluative and analytical & $\begin{array}{l}\text { Ability to analyze the state of administrative documents, work with expert systems for selecting candi- } \\
\text { dates for the positions of academic staff members, basic qualimetric models of activities; analyze } \\
\text { qualitative indicators of academic and scientific performance ability for working in an expert group, } \\
\text { pedagogical reflection. }\end{array}$ \\
\hline Technological & $\begin{array}{l}\text { Command of monitoring technologies; ability to design, develop and use innovative management } \\
\text { technologies, algorithms, models, methods; to identify the technological component of the system of } \\
\text { university management; to implement innovative technologies in management. }\end{array}$ \\
\hline Communicative & $\begin{array}{l}\text { Communication skills; communicative competence; command of communication technique, negotia- } \\
\text { tion; knowledge of the rules of administrative ethics and recognition of its norms; skills of establishing } \\
\text { communication with the subdivisions of MES; knowledge of diplomacy; speech culture; compliance } \\
\text { with the rules of business communication; ability to be partnering with the academic staff and stu- } \\
\text { dents; skills of using information and communication technologies in university management; ability } \\
\text { to use critical thinking methods; command of a foreign language. }\end{array}$ \\
\hline Conceptual & $\begin{array}{l}\text { Ability to develop plans, programs, projects; knowledge of qualitative indicators of university man- } \\
\text { agement. }\end{array}$ \\
\hline $\begin{array}{l}\text { Acmeological orientation } \\
\text { of management activities }\end{array}$ & $\begin{array}{l}\text { Intentions (aspiration) to develop professionalism in management activities; high level of creativity } \\
\text { development; readiness for self-development, development of acmeological knowledge, abilities and } \\
\text { skills in management activities. }\end{array}$ \\
\hline $\begin{array}{l}\text { Motivational and } \\
\text { purpose-oriented }\end{array}$ & $\begin{array}{l}\text { Ability to develop a "goal tree", to introduce the system of incentives for AS and students; self- } \\
\text { motivation for management activities. }\end{array}$ \\
\hline Organizational & $\begin{array}{l}\text { Ability to provide organizational and pedagogical, psychological conditions for efficient work of AS, } \\
\text { students, structural units of a university; to organize management activities in accordance with the } \\
\text { legal framework. }\end{array}$ \\
\hline Personal & $\begin{array}{l}\text { The formation of personal, business, professional, ethical, leadership qualities, creativity, manage- } \\
\text { ment-related knowledge (theoretical, methodological); job description of a university leader, creative } \\
\text { initiative; intent to modernize management activities and use innovations. }\end{array}$ \\
\hline Core competencies & $\begin{array}{l}\text { High level of formation of methodological and technological knowledge and skills; the use of informa- } \\
\text { tional management methods (data base management systems); command of the state language. }\end{array}$ \\
\hline $\begin{array}{l}\text { General and specific } \\
\text { competences }\end{array}$ & $\begin{array}{l}\text { Instrumental competences (cognitive skills, linguistic skills); ability to put knowledge in practice; } \\
\text { communication skills; ability to plan changes; to understand a problem comprehensively; adaptive } \\
\text { capacity; knowledge of business etiquette. }\end{array}$ \\
\hline Specific competences & $\begin{array}{l}\text { Research abilities and skills; ability to generate new ideas; see into the context; methodical knowledge } \\
\text { and abilities; ability to use logical methods of critical analysis; assess the quality of research findings } \\
\text { in a particular branch of knowledge; develop new technologies. }\end{array}$ \\
\hline Performance review & $\begin{array}{l}\text { Professional qualification profile of a leader according to the content of management activities; thesis } \\
\text { defense; experience of scientific and pedagogical work and work as a leader of a higher educational } \\
\text { institution; printed academic and research papers; academic title; preparing candidates of sciences. }\end{array}$ \\
\hline Career development & $\begin{array}{l}\text { Internship in sectoral research institutes, abroad; taking special programs at career development cours- } \\
\text { es; retraining in the specialty "Management"; participation in international conferences, scientific and } \\
\text { methodological seminars; learning foreign languages of European Union countries. }\end{array}$ \\
\hline Research & $\begin{array}{l}\text { Managing scientific schools, research laboratories; preparation of theses; reviewing and being oppo- } \\
\text { nent for thesis defense; writing reports on extended abstracts of theses; being chairman in the state } \\
\text { examination board. }\end{array}$ \\
\hline
\end{tabular}


In the process of competitive selection for the position of a leader of a higher educational institution, it is necessary to consider the components of the job description (Table 3).

Components of the job description of a higher educational institution leader

\begin{tabular}{|c|c|}
\hline Personal profile & Psychological profile \\
\hline $\begin{array}{l}\text { - Qualification (basic education) } \\
\text { - Qualities (personal, professional, business, ethical) } \\
\text { - Professionalism (competence, management skills) } \\
\text { - Special (managerial) competences: knowledge, abili- } \\
\text { ties, skills acquisition, methods of professional activi- } \\
\text { ties: data processing, organization of the process) } \\
\text { - Degree of training in management } \\
\text { - Managerial roles (a leader, a strategist, a coordinator } \\
\text { of personnel's activities; an organizer of resource allo- } \\
\text { cation, negotiation; an informant, a consultant, a facili- } \\
\text { tator). }\end{array}$ & $\begin{array}{l}\text { - Internal motivation (needs, interests, aspirations) } \\
\text { - Capabilities } \\
\text { - Psychophysiological characteristics (temperament, } \\
\text { character, volitional qualities) } \\
\text { - Self-concept (attitudes, values) } \\
\text { - Creative potential } \\
\text { - Resilience to stress } \\
\text { - Self-reflection } \\
\text { - Self-actualization } \\
\text { - Readiness for personnel management }\end{array}$ \\
\hline Descriptive profile & Acmeological profile \\
\hline $\begin{array}{l}\text { - Independence } \\
\text { - Responsibility for the results of activity of a higher } \\
\text { educational institution } \\
\text { - Integration into academic space (communication) } \\
\text { - Transparency of activity results }\end{array}$ & $\begin{array}{l}\text { - Position } \\
\text { - Academic degree } \\
\text { - Academic title } \\
\text { - Publication activity } \\
\text { - State awards } \\
\text { - Honorary titles } \\
\text { - Career development, international internship } \\
\text { - Innovations }\end{array}$ \\
\hline
\end{tabular}

Each of the above-mentioned components of managerial competence has corresponding requirements developed by us. The monitoring of quality indicators of university leader's management activities for the last five years should take into account the components of the job description (personal profile, psychological profile, descriptive profile, acmeological profile (Table 3).

For the development of university leader's managerial competence we have worked out a special program (Figure 1).

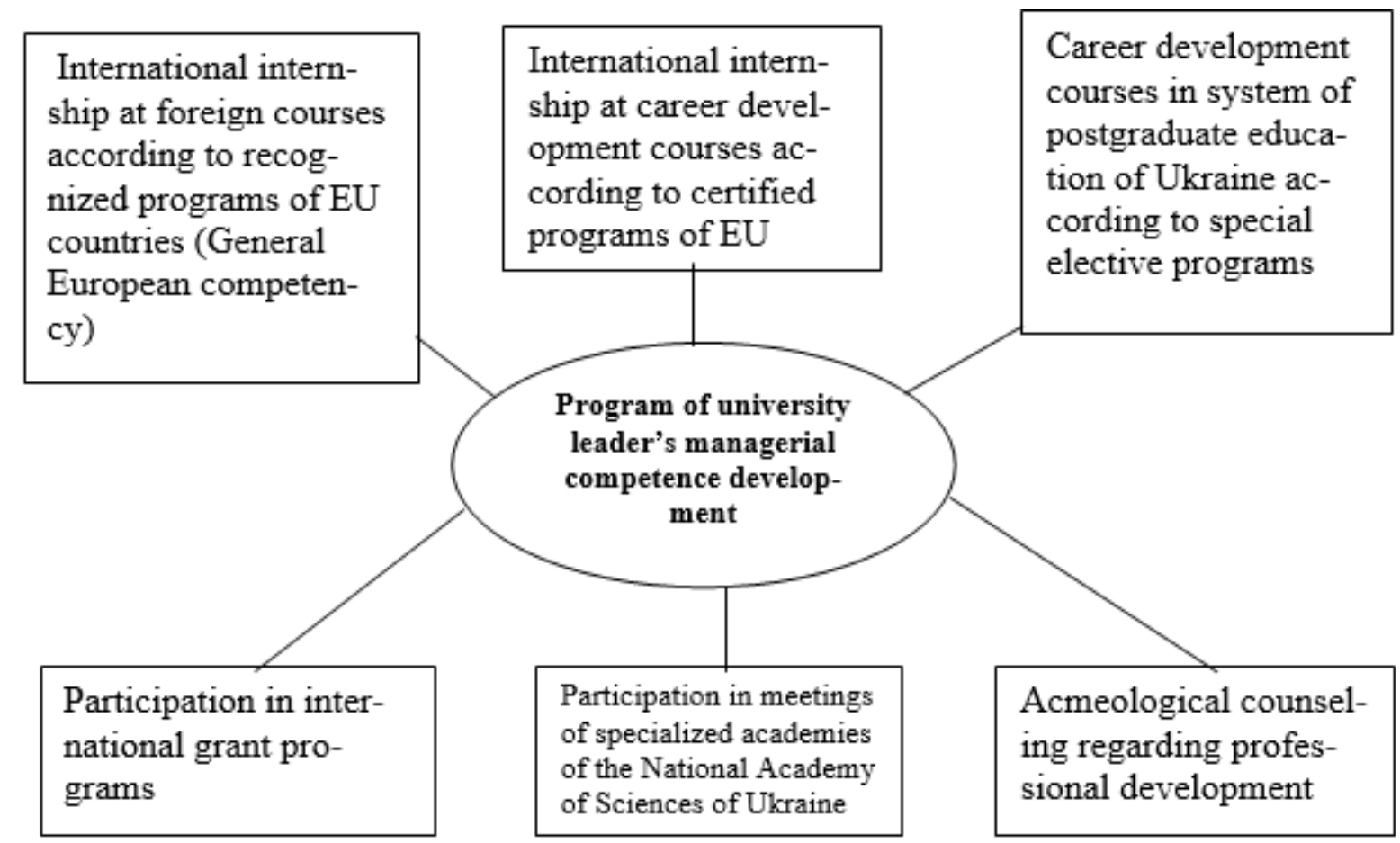

Figure 1. Program of university leader's managerial competence development 
As can be seen the program of university leader's managerial competence development involves the following organizational measures: international internship at foreign courses according to recognized programs of EU countries, international internship at career development courses according to certified programs of EU countries, taking career development courses in the system of postgraduate education of Ukraine according to special elective programs, participation in international grant programs, participation in meetings of specialized academies of the National Academy of Sciences of Ukraine, acmeological counseling regarding professional development.

The program of the learning module of career development courses for university leaders implies the mastering of the following disciplines: strategic management, contextual management, psychology of education management, data base management systems, administrative ethics, innovation management in education, legal aspects of managing universities, occupational safety, health and safety, marketing in higher education, management of innovation projects; monitoring the quality of education, interests and requirements of educational services consumers.

The conception of managing the development of university leader's competency is implemented in the system of postgraduate education in the process of career development at the State Higher Educational Institution "University of Education Management" of the National Academy of Educational Sciences of Ukraine, State Academy of Senior Executives of Education, National Academy for Public Administration under the President of Ukraine.

Conclusions. Organizational condition for efficiency of competitive and diagnostic selection (based on the resultant approach) of candidates for the position of a leader of a higher education establishment is a creative technology (legal framework, theoretical model of selecting candidates for the position of a university leader, the standard of professional management of university lead-

\section{REFERENCES}

1. Zakon Ukrainy "Pro vyshchu osvitu" vid 1 lypnia 2015 № 1556- VII [The Law of Ukraine “On Higher Education" dated July 1, 2014, No. 1556-VII]. Holos Ukrainy - Voice of Ukraine, 148, 9-19 [in Ukrainian]

2. Dessler, G. (1997). Upravlenie personalom [Personnel management]. (D. Konkova, Trans.). Moscow: Binom [in Russian].

3. Yelnykova, H. V. (2003). Naukovi osnovy adaptyvnoho upravlinnia zakladamy ta ustanovamy zahalnoi serednoi osvity [Scientific bases of adaptive management of institutions and establishments of secondary education]. Doctor's thesis. Kyiv: DVNZ "Universytet menedzhmentu osvity" [in Ukrainian].

4. Yelnykova, H. V. (1999). Naukovi osnovy rozvytku upravlinnia zahalnoiu serednoiu osvitoiu $v$ rehioni [Scientific bases of managing the development of er's competence development, job description, the program of university leader's managerial competence development). It contributes to democratization of mechanisms of functioning of the open system of selecting candidates for the position of a university leader by means of managerial functions of the process of university leader selection and his/her competence development in the system of postgraduate education, namely organization, coordination, planning, analysis, control and forecasting.

\section{Recommendations}

1. To implement a transparent procedure of assessing the qualitative characteristics of the level of managerial competence of candidates for the position of a leader at higher educational institutions. The system of candidate selection should include a subsystem of the formation and training of managerial personnel reserve for universities, information subsystem (containing personal data of candidates who are included in the reserve).

2. To form the reserve of candidates for the position of a higher educational institution leader at the university.

3 . To create a database about the reserve of candidates to fill managerial positions.

4. To organize the training of managerial personnel reserve (for colleges, vocational schools) when students are receiving their Master degrees in the specialty "Management" at the University of Education Management of the National Academy of Educational Sciences of Ukraine (depending on the type of a higher educational institution).

5. To post information about announcing a competition to fill the vacancy of a leader of a higher educational institution in the media and on the official website of this university in due time.

6. To spread the use of expert systems, new technologies of competitive selection for the position of a university leader.

7. To improve the current legislation that regulates the procedure of selecting candidates based on the experience of European countries.

secondary education in the region]. Kharkiv: Derzhavna akademiia kerivnykh kadriv osvity [in Ukrainian].

5. Karloff, B., \& Sederberg, S. (1996). Vyzov liderov [Challenge of leaders]. (D. Lindberg, Trans.). Moscow: Delo [in Russian].

6. Metodychni rekomendatsii shchodo osoblyvostei vyborchoi systemy ta poriadku obrannia kerivnyka vyshchoho navchalnoho zakladu [Recommended practice concerning peculiarities of the voting system and procedure of electing university leaders]. (n. d.). osvita.gov.ua. Retrieved from: http//osvita.gov.ua [in Ukrainian].

7. Row, R. (2012). Podbor personala v Evrope: kontekst, perspektivy i programma issledovaniia [Personnel selection in Europe: context, prospects and research program]. Organizatsionnaia psikhologiia - Organizational psychology, 3, 39-66 [in Russian]. 
8. Standarty i rekomendatsii shchodo zabezpechennia yakosti v Yevropeiskomu prostori vyshchoi osvity [The standards and recommendations concerning assurance of quality in the European environment of higher education]. (n. d.). enga.eu. Retrieved from: http//enga.eu/files/ESG\%20in\%20ukrainian.pdf Ukrainian].

9. Stepashko, V. O. (2004). Orhanizatsiinopedahohichni umovy formuvannia vykladatskoho personalu u vyshchykh navchalnykh zakladakh [Organizational and pedagogical conditions of forming the teaching staff in the higher educational institution]. Extended

\section{ЛІТЕРАТУРА}

1. Закон України «Про вищу освіту» : прийнятий 1 лип. 2014 року № 1556 -VII // Голос України. 2014. - № 148. - С. 9-19.

2. Десслер Г. Управление персоналом / Г. Десслер ; пер. с англ. Д. Конькова. - М. : Бином, 1997. - 799 c

3. Сльникова Г. В. Наукові основи адаптивного управління закладами та установами загальної середньої освіти : дис. ... доктора пед. наук : 13.00.01 / Галина Василівна Сльникова. - К. : ДВНЗ «Університет менеджменту освіти», 2003. - 453 с.

4. Сльникова Г. В. Наукові основи розвитку управління загальною середньою освітою в регіоні: навч. посіб. / Г. В. Сльникова. - Х. : Державна акад. керівних кадрів освіти, 1999. - 301 с.

5. Карлофф Б. Вызов лидеров / Б. Карлофф, С. Седерберг ; пер. с швед. Д. Линдберг. - М. : Дело, 1996. - $354 \mathrm{c}$

6. Методичні рекомендації щодо особливостей виборчої системи та порядку обрання керівника вищого навчального закладу [Електронний ресурс]. Режим доступу : http//osvita.gov.ua. abstract of candidate's thesis. Ivano-Frankivsk: Prykarpatskyi un-t imeni Vasylia Stefanyka [in Ukrainian].

10. Chandler, A. D. (1962). Strategy and structure. London: MIT Press [in English].

11. Hannan, M., \& Freeman, I. (1989). Organizational ecology. Harvard University Press [in English].

12. Hofstede, G. (2001). Culture's consequences: comparing values, behaviors, institutions and organizations across nations. Thousand Oaks, CA: Sage Publications [in English].

7. Роу Р. Подбор персонала в Европе : контекст, перспективы и программа исследования / Р. Роу // Организационная психология. - 2012. - Т. 2. - № 3. C. 39-66.

8. Стандарти і рекомендації щодо забезпечення якості в Свропейському просторі вищої освіти [Електронний ресурс]. - Режим доступу http//www.enga.eu/files/ESG\%20in\%20ukrainian.pdf

9. Степашко В. О. Організаційно-педагогічні умови формування викладацького персоналу у вищих навчальних закладах : автореф. дис. на здобуття наук. ступеня канд. пед. наук : спец. 13.00.01 «Загальна педагогіка та історія педагогіки» / В. О. Степашко. Івано-Франківськ : Прикарпатський ун-т імені Василя Стефаника, 2004. - 19 с.

10. Chandler A. D. Strategy and structure / A. D. Chandler. London : MIT Press, 1962.

11. Hannan M. Organizational ecology / M. Hannan, I. Freeman. Harvard University Press, 1989.

12. Hofstede G. Culture's consequences: comparing values, behaviors, institutions and organizations across nations / G. Hofstede. Thousand Oaks, CA : Sage Publications, 2001.

Володимир Олексійович Степашко, доктор педагогічних наук, дочент,

професор кафедри освітнього менеджменту та освіти дорослих, Переяслав -Хмельницький державний педагогічний університет імені Григорія Сковороди, вул. Сухомлинського, 34, м. Переяслав-Хмельницький, Украӥна

\section{ТЕХНОЛОГІЯ КОНКУРСНОГО ВІДБОРУ ПРЕТЕНДЕНТІВ НА ПОСАДУ РЕКТОРА ВИЩОГО НАВЧАЛЬНОГО ЗАКЛАДУ}

У статті розглянуто проблему науково обгрунтованого професійного конкурсного відбору претендентів на посаду керівника вищого навчального закладу на основі компетентнісного, факторного та результатного підходів. Розроблено адаптовану до умов функціонування ВНЗ кваліметричну факторно-критеріальну модель оцінювання якісних показників рівня розвитку, програму розвитку управлінської компетентності, теоретичну модель відбору претендентів на посаду керівника вищого навчального закладу. У кваліметричній моделі визначено чотири фактори: конкурентоспроможність, творчий потенціал, управлінська компетентність, умови формування управлінської компетентності, які визначають результативність управлінської діяльності керівника вищого навчального закладу. У програмі розвитку управлінської компетентності керівника ВНЗ ми визначили такі організаційні заходи: міжнародне стажування за ліцензованою програмою курсів іноземних умов країн Євросоюзу Загальноєвропейської компетенції; міжнародне стажування на курсах підвищення кваліфікації за сертифікованими програмами країн Євросоюзу; навчання на курсах підвищення кваліфікації в системі післядипломної освіти України за спеціальними варіативними програмами; участь у міжнародних грантових програмах; 
участь у засіданнях зборів галузевих академій НАН України; акмеологічне консультування з питань професійного розвитку. Теоретична модель відбору претендентів на посаду керівника вищого навчального закладу складається з чотирьох етапів. Перший етап утворюють підсистеми комп'ютерного експертного діагностування (анкетування претендентів) та попереднього конкурсного відбору. На другому етапі засновник організує інтелектуальне тестування (спеціалізований тест, а також тест на перевірку знань іноземної мови, математики). На третьому етапі («Експертне оцінювання») засновник організує одночасно 3 демократичною процедурою обрання ректора у ВНЗ співбесіду експертної кадрової комісії МОН України з кандидатом. На четвертому етапі оцінюються кількісні показники рівня розвитку управлінської компетентності претендентів на основі кваліметричної моделі. Рекомендовано упроваджувати у ВНЗ прозору процедуру оцінювання якісних показників рівня управлінської компетентності претендентів на посаду керівника. Система відбору кандидатів має включати підсистему формування й навчання резерву керівних кадрів ВН3, інформаційну підсистему, яка містить персональні дані претендентів. Крім того, необхідно розширити застосування експертних систем, нових технологій конкурсного відбору на посади керівників вищих навчальних закладів; удосконалити діюче законодавство, що врегульовує процедуру відбору кандидатів на основі практичного досвіду європейських країн.

Ключові слова: професійний відбір, кваліметрична модель, моніторинг, модель відбору, керівництво.

Submitted on May, 30, 2017 